\title{
RELIGION, IDENTITIES, AND POLITICS: DEFINING MUSLIM DISCOURSES IN THE NUBA MOUNTAINS OF THE SUDAN
}

\author{
Leif Ole Manger
}

\section{BERGEN}

\begin{abstract}
The author discusses the increased importance of Islam in religious and social life in the Sudan, exemplified by a discussion of the interplay between an indigenous, non-Arab, non-Islamized Sudanese people, the Lafofa Nuba, and their interaction with the Arab and Islamic traditions of Sudanese society at large. An understanding of this interaction will require types of analysis that deal with issues of belief as well as broader issues of identity management. People do not take over Islam as one unified system and in one process of conversion; rather they take up Muslim customs and practices that become symbols of such a conversion. The process of conversion must therefore be linked to the socio-economic and political status of the people involved. The author points out that theoretical contributions by Talal Asad on Islam as a "discursive tradition" and Robert Launay on Muslim communities as "moral communities" provide interesting avenues for exploring this complexity.
\end{abstract}

In 1966 the anthropologist Ian Lewis wrote in the introduction to his seminal book Islam in Tropical Africa that "as with Christianity in the West, Islamic civilization is being gradually detached from its religious roots, and the gulf between the spiritual and the secular spheres of life is widening. While, as elsewhere in the Muslim world, continuing to influence deeply the private lives of individuals, it is thus at least questionable whether Islam can be expected in the future to exercise the profound political effect it has had in earlier periods of African history" (Lewis 1966, 91).

In 1993 the fundamentalists in the Sudan gave the following "comment" on Lewis's prophecy:

Bismillahi Al-Rahmani Al-Raheem (In the Name of Allah the Beneficent, the Merciful)

Praise be to Allah, and due prayers and peace be unto the messenger of Allah.

The conference of the Ulamah (scholars in Islamic Studies), the imams of mosques, and the sheikhs of the Sufi sects in the State of Kordofan, which was held at the Peoples Committee Hall, in El-Obeid, on 24 Shawwal 1413 (the 
Muslim hijrah calendar), which corresponds with 27 April 1993,

Hereby issue the following Fatwa about the imperativeness of mobilizing for jihad (holy war) in order to fight in the war which is taking place in the southern part of Kordofan State and in Southern Sudan, and therefore resolve the following:

1. The rebels in Southern Kordofan or in Southern Sudan have rebelled against the state and have waged war against Muslims, with their prime objective being the killing and massacring of Muslims, the destruction of mosques, the burning [of] copies of the Quran, and violating the honour and dignity of Muslims, while the rebels are being driven and instigated by the enemies of Islam from amongst the Zionists, the Christian Crusaders, and the forces of arrogance, who have been supplying them with food and arms. Therefore, the rebels who are Muslims and are fighting against the state are hereby declared apostates from Islam, and the non-Muslims are hereby declared kaffirs (infidels) who have been standing up against the efforts of preaching, proselytization, and spreading Islam into Africa. However, Islam has justified the fighting and the killing of both categories without any hesitation whatsoever with the following Quranic evidence; Allah said "Oh you who believe, if there will be anyone who becomes an apostate from amongst yourselves away from Islam, Allah will bring about another nation who will love him and he loves them, of those who are humble towards the believers, and proud (in their behaviour) above the kaffir, they will struggle in jihad for the sake of Allah, and will not heed to any blame which may be levelled against them by anyone. This is the favour of Allah which he gives to whom he wishes, and that Allah is omnipresent, and all knowing."1

The point here is not to expose Lewis's lack of prophetic skills, a deficiency to which most of us have to confess, but rather to point at some of the underlying assumptions behind views such as the one he expressed: first, that there is an underlying dynamic that the religious and political spheres will part ways and that religion will increasingly be confined to the private sphere, and second, that the model case is, as in so many other examples, the Western and Christian experience. The quote is interesting in that it shows how anthropology in general, in this case religious anthropology in particular, reflected the dominant mod-

\footnotetext{
${ }^{1}$ Quoted from the English translation sent by the Sudan Discussion list <SUDAN-L@EMUVM1.BITNET>, Aug. 16, 1995. The translation is reported to have been made by the Nuba Mountains Solidarity [Abroad] (NMSA). Minor changes in spelling, capitalization, and punctuation have been made. The names of the alleged signers of the fatwa, which were included in the e-mail message, have been omitted. The remainder of the text is cited at the end of the paper.
} 
ernization theory assumption of the day, namely, that the more a society "modernizes" the less religious it will become.

Obviously, we need not elaborate on the fatwa cited here to make the point that Islam is indeed alive and well in the political field. And the issue is the definition of being a Muslim, that is, belonging to Dār alIslām, as opposed to Dār al-Harb. But this is not new. At all times there has been disagreement within Islam about what it means to be a Muslim and the fact that, from time to time, some of these disagreements enter the political field should not surprise us. Certainly it is of interest to analyze cases of "political Islam," but I also feel we should not only look at Muslim politicians but pay more attention to how "ordinary" Muslims themselves argue concerning this issue, not only within the field of political Islam, but also in everyday discourses about what is right and wrong, what is proper behavior, and the like. Although less spectacular than fatwas about jihad, such mundane issues may nevertheless enhance the understanding of how Muslims themselves experience their religion.

This call for jihad also raises certain conceptual challenges. How can we conceptually approach the diversity of Islam in terms of beliefs as well as practices? In one sense there are as many Islams as there are situations that sustain them. Hence a critical point is to acknowledge the importance of context, be it local as in "village Islam," regional as in "West African Islam," or national as in "Indonesian Islam" and "Moroccan Islam." But Islam is much more than a product of any local, regional, or national situation. It has a global nature, in that for believers it contains generalized truths and is in that sense very real. For instance, the general notion of umma makes all Muslim people belong together in a specific relationship to God characterized by equality. The same equality is expressed in the Quran as well as in other religious texts. However, Muslims living in any real society may find themselves characterized by inequalities, based on age, gender, social status, or the like, that are products of other socio-historical forces than Islam itself. However, in a Muslim society, discourses relating to such local realities are couched in Islamic idioms, or are couched in discourse that resonates with the Islamic one, be it by way of opposing it or not. This means, for instance, that discourses about such inequalities are legitimized and given authority by relating them to various standard Islamic notions of authority and the basic Islamic texts (Koran, sunna, and the legal and ethical works that make up $\operatorname{shari}^{c} a$ ). But they cannot be reduced to such readings and interpretations of religious and esoteric texts alone. First of all, the basic texts may not be at all unified. Shari ${ }^{c} a$, for instance, is not made up of a single collection of texts, but consists of the accumulated body of many 
texts from many centuries and many continents. Furthermore, people may not have direct access to such texts and may depend on interpretations given by local literate people, or their own interpretations of events and information brought to them through different sources. Thus there are a multiplicity of voices involved in such interpretations, not only the voices of scholars with texts at hand but also those of "ordinary" Muslims, diversified as they are in age, gender, class, ethnicity, education, and so on, a factor that further strengthens the notion that Islam consists not only of the cosmological themes of the canonical texts and subsequent religious treatises but also of lived identities in local contexts, emerging within ongoing debates about what is right and what is wrong (Manger 1999).

Talal Asad in his 1986 article "The Idea of an Anthropology of Islam" offers conceptual tools to handle this type of diversity. He is critical of those who involve themselves in the search for the essence of Islam, and he suggests we look at Islam as a discursive tradition, in which our task is to understand the production of knowledge and the institutional conditions for the production of that knowledge. We should not assume religion and culture to make up any a priori system of meaning and we should not look for what is essential in Islam. Rather we should look for historical formations through which what is taken to be essential in Islam is being produced. In this perspective, Islam does not become an active agent but an arena of many processes that become Islamic because they belong to the discursive tradition of Islam. The tradition consists essentially of discourses that seek to instruct practitioners regarding the correct form and purpose of a given practice that, precisely because it is established, has a history. Hence the discourses "relate conceptually to a past (when the practice was instituted and from which the knowledge of its point and proper performance has been transmitted) and a future (how the point of that practice can best be secured in the short or long term, or why it should be modified or abandoned), through a present (how it is linked to other practices, institutions, and social conditions)" (p. 14). The discursive tradition also has its social organization, including experts on different levels - with knowledge, with specific technologies for transferring their knowledge, with internal hierarchies, but also with relations to rulers, and so on. The question here is not one of seeking the essence of Islam, but of knowing the historical conditions necessary for the existence of particular religious practices and discourses.

Asad's perspective fits well together with Robert Launay's suggestion in his 1992 book Beyond the Stream: Islam and Society in a West African Town. His proposal is to see the Islamic community as a moral 
community, that is, a community to which the members consciously belong, and in which there is a moral discourse about that belonging. By this Launay is able to bring in the Muslims' own conceptualizations of their own community - who belongs and who does not, what acts are moral and which ones are not. By using the concept of "moral community" one can also see how general Islamic norms and local ones come together to shape a local reality. This does not mean that there is only one discourse, or that there is agreement about what is authoritative. But that is no problem for our analysis. The notion of discourse analysis, or of culture as "conversations rather than structures" (Lambek 1992), does not impose such rigor. Many discourses or conversations can go on simultaneously and they do not have to be internally "coherent." People can participate in many discourses without losing their coherence as persons. Inconsistencies do not lead to breakdown, but are sources for further conversations.

Differences in form should therefore not be reduced to an anthropological problem of classification. Our task is not to decide whether acts, statements, rituals, and the like can be classified as Islamic or nonIslamic, political or non-political, public or private, traditional or modern. Rather, our aim is to see how Muslims themselves make use of such differences in their own lives. Furthermore, Muslims are well aware of differences and inconsistencies, within their own society as well as between their own society and others. But unlike the case with anthropologists, such comparisons made by Muslim people (and others, for that matter) are not intellectual exercises. They are very real, and they constitute the basis for the shaping of identities. This can go on in the form of peaceful processes, but identities (as our quote shows) can also sometimes appear in violent opposition to each other, and the struggles can lead to new evaluations about what is perceived as Islamic.

Let me illustrate these points by discussing the case of the Nuba Mountains in the Sudan, one of the areas targeted for jihad in the fatwa cited above. Our discussion will show that the problem of defining who is a Muslim in no way started with the Muslim Brother takeover of state power in 1989. Rather, as suggested by Asad, we might have to look in other directions than what conventionally is termed the religious field and "political Islam."

\section{What Constitutes Being a Muslim?}

While doing fieldwork (late 1970s, early 1980s) among the Lafofa Nuba in Central Sudan I was struck by the way people presented themselves as being Muslims (Manger 1994). Any Lafofa would claim to be Muslim, 
but there was no agreement among people that their neighbors actually deserved this label. Older people would talk about their old way of life that they left long ago, when they went without clothes and when they kept pigs. But today they claim to be Muslims although they still treasure the memory of those bygone days. Younger men argued strongly that the elders were still holding on to the pre-Islamic customs; they are ignorant and do not understand the modern world, the young Lafofa claimed. Talking to groups of non-Lafofa in Liri, they would hardly recognize any Lafofa as being a Muslim. They recognized the fact that some of the young people were trying to leave their old ways and become Muslims, but few of them were known to pray and even fewer were fasting.

This evident difficulty in agreeing on who is a Muslim, and what it entails to be one, is not something that is special for the Lafofa and the southern Nuba Mountains. In most Muslim areas there are constant debates over what is proper Islam and what is not, what behavior is derived from proper Islamic principles and what derives from other sources. What is special in this case is that the Lafofa, as a Nuba group, is a nonArab, non-Islamic people among whom the process of conversion is a contemporary phenomenon. The debates in Liri are thus not only between different Islamic traditions but between an Islamic tradition and a non-Islamic, tribal one. But such a discussion cannot focus on religion in isolation. The way the Lafofa participate in this discourse is not an isolated process of religious conversion, but is in a basic way a product of a people adapting to the realities of the day. Hence the discussion must deal with wider social identities. The determination of personal identity has always been an issue in the Nuba Mountains. As a frontier region with a history of slave hunting, of exploitation of ivory and gold, and of being part of the battlefield between earlier savanna states there has always been a high rate of movement, resettlement and coming together of new groups. The establishment of one's identity within broader categories such as Nuba/Arab, slave/freeman, non-Muslim/Muslim has always been of importance. I have earlier written on various dimensions of these processes (Manger 1992a, 1992b, 1994, 1999). Here I shall try to summarize some of the basic processes.

\section{The Nuba of Liri: Some Major Changes}

The Lafofa is one of the matrilineal Nuba groups in the southern parts of the Nuba Mountains. Like many other groups they have gone through processes of "Arabization" and "Islamization" in this century, leaving many changes in their cultural tradition. This is evident in numerous fields of their lives. For instance, marriage was not previously a major 
ceremonial occasion for the Lafofa. Young people arranged their own love affairs, and if two people decided to marry they would tell their parents, who would normally accept their decision. The link between the bridegroom and the bride's family was institutionalized in a bride service relationship. The wedding itself was a minor thing, although there was a party in which drinking beer was an important element.

The institutions that were decisive in regulating any person's life, and providing him or her with people to cooperate with, were not only found within the realm of the family and in-laws. In the daily life of a person age-mates were also of great importance. There were seclusion ceremonies that took place shortly after puberty had been reached. Boys would spend the rainy season taking care of the cattle and they would live in cattle kraals. At the end of such a period of seclusion they would return and a ceremony would be performed. For girls, the transition ceremony meant seclusion in the granary, a practice which brought out clearly the relationship between menstruation and female fertility on the one hand and the production of food for the reproduction of the groups as such on the other. A final institution that regulated people's lives was the existence of certain experts in the villages, called kujūr. The most important of them was the rainmaker. He was a man of great dignity, possessing powers from the ancestors to bring the rain that is so crucial for cultivation. For his services to the community, the rainmaker had his plot cultivated for him, and he was also paid in beer. Apart from the rainmaker, there were other domain experts who operated along the same principles. There were experts for each of the important crops. Sickness experts were also important, as they could cure people through their powers. And finally, there was an iron expert. A common way of paying all these experts was in beer.

The general framework of the social organization outlined above has undergone changes through the decades of this century. The matrilineal principle is still there, but it is not as critical an organizational principle as it used to be. Marriage is totally changed, being now permeated with Arab customs and ruled by Islamic $\operatorname{sharī}^{c} a$ principles. The position of the rainmaker and other experts is challenged by Islamic holy men, who perform the same functions, relating their powers to Allah instead of the ancestors of the group. The age grade system is no longer a living institution among the Nuba of the southern mountains and the seclusion periods no longer exist. Today the transition ceremonies are the Islamic ones - name-giving, circumcision (of both girls and boys), and marriage. The ceremonies are individual and the Islamic holy men provide the blessing. At the death of a person he or she is buried in an individual 
grave, not in the former lineage graves. The ceremony is Islamic, with a seven-day mourning period.

These developments are of far-reaching importance for the ways Lafofa ritual traditions are reproduced and changed. The old rituals were all occasions on which Lafofa social and ritual life coalesced and could be expressed and reinforced. Furthermore, the ritual cycle was organized around the cultivation cycle, tying together economic and ritual life. The rainmaker kujür was the pivotal point around whom all this revolved, and his house was an important spatial center for this ritual life. This is very different from the outwardly oriented organization and lay-out of the Islamic rituals into which the Lafofa are drawn. On a general level such rituals are organized around the five daily prayers and the important Friday prayer, the mosque being the point of reference. Other references are the month of fasting, Ramadan, and the pilgrimage to Mecca. The local Islam of Liri revolves around the Qādirīya Sufi center and the leading sheikh there, and from this brotherhood come the fuqara (sing. faki, faqīh) who have replaced the kujürs. I have elsewhere shown how the dynamics of these changes can be interpreted. For the purposes of this paper I need to elaborate on the historical contexts of the changes.

\section{Nuba Identities in Different Historical Contexts}

One major characteristic of the southern parts of the Nuba Mountain region is that it is inhabited by many groups that are not original inhabitants of the area but who have settled there as a result of earlier events. A major factor relates to the situation on the southern frontier in eighteenth- and nineteenth-century Sudan. The distribution of adaptive groups in the region during this period was very much influenced by the problem of security. The area was a frontier region, like the Ingessana Hills and Dār Fartīt, being subject to human and economic exploitation by the various power holders that controlled the regions to the north. These power holders were, first, the larger pre-colonial savanna states, Funj and Darfur, the Turco-Egyptian regime (after 1821), and finally the Mahdist state, but some areas were also within the area of one of the smaller pre-colonial states, the Taqali kingdom. As mentioned, the general theme during this period was the exploitation of the Nuba Mountains for ivory, gold, and, most importantly, slaves. All the power holders mentioned were Muslims, who were attacking the non-Muslim Nuba population - the Nuba being the main target of slave raids.

The identity of the slave hunters varied, but apart from official slave hunting expeditions organized by the states themselves, the main groups involved were the immigrant groups, namely, the Arab pastoralists and 
the jallāba traders. The pastoralists used the Nuba Mountains area for pasture, which brought them deep into the mountains and into contact with the inhabitants. During these migrations the Arab pastoralists would raid and take slaves from different Nuba groups. The system varied. In some hills they would develop relations with Nuba leaders, who would provide slaves from other groups in order to save their own populations. In other areas the Nuba were raided directly by the pastoralists. In all instances, however, the system was based on inequality of power. The jallāba traders' involvement in slave-taking and the slave trade was particularly significant for them. Many traders became rich through these activities and the capital gained from the slave trade became the start of many jalläba trading houses in the west.

The basic pattern of this exploitation of the Nuba Mountains did not change much throughout the period before 1900, except in the intensity of exploitation. The Turco-Egyptian regime demanded more slaves and taxes from the inhabitants than had the pre-colonial kingdoms, and they had a stronger machine for securing what they wanted. The level of exploitation thus increased in the nineteenth century. But generally, developments during these periods left the Arab pastoralists and the traders as groups with superior power, able to exploit the Nuba inhabitants. Developments during the Mahdist period increased the pressure on these outlying areas and led to the dramatic resettlement of various groups. The most important of these developments was the outbreak of war in the 1880 s.

For the Nuba a basic problem was how to organize themselves for defense in order to survive in their home areas. This could be partly achieved by hiding in their mountains where the horses of the slave raiders could not enter, the task of defense being thus made easier. But political allegiances were also at work, showing that the situation was not completely anarchic. There were smaller political units ruled over by local leaders called meks. They owed allegiance to greater rulers above them, and the link was maintained through payments of tribute. This description is particularly relevant for the Lafofa who, before settling in Liri, lived in Tekeim, an area to the east of the Liri Mountain. Tekeim was part of the area controlled by one of the Taqali meks, at Jebel Gadir. The mek of Gadir ruled over areas where there were Nuba inhabitants as well as various Arab groups. The people under him were the Kau, Fungor, Werni, Kalogi, Tira, Talodi and possibly the eastern Moro. My own material shows that according to Lafofa tradition a daughter of the Lafofa mek Deldung was married to the mek Bosh of Gadir, indicating the existence of a political relationship that could well be related to the 
need for security.

It is in this context we should see the Nuba involvement with Islam at the time. Islam was not a matter of private and individual belief, but rather a chosen identity that tied Nuba groups to power holders who were Muslim. By being categorized together with such leaders as being Muslims, some groups managed to become defined outside the group eligible for enslavement by Muslims. Aside from birth in slavery, the only lawful source of slaves in Islam was the capture of non-Muslim prisoners of war. Muslims could not be reduced to slavery (Encyclopaedia of Islam [1960] 1986, 1:26a).

Building a similar picture for the developments in the 20th century involves a description of various policies during the period of British colonial rule as well as the various regimes following Sudanese independence after 1956. Again, my aim is to focus on patterns, not on detail.

Compared to the earlier period, the years of the British rule in the Nuba Mountains brought profound changes. Two such changes were the pacification of the area and the abolition of slavery. The British strategy, finding the Nuba in their hills and the Arabs on the plains, was first to bring the Arabs under control. They posed the most serious military threat but were also of immediate economic interest to the British, since they had cattle, the only cash commodity of the day. After the Arabs had been pacified, the Nuba were subdued, often through punitive patrols and forced down-migration from the hills into the plains, where they could be more easily controlled.

The British presence also brought changes to the economic environment of the area. To rule the region the British established military and administrative towns, centers that also grew into markets where the expanding exchange of goods could take place. Contact between these towns and others was improved by the construction of new roads and the introduction of motorized vehicles. Developments thus moved towards opening up the previously closed area. In the early period of their occupation of the Sudan the British built the Sennar Dam on the Blue Nile to get water for the Gezira irrigation project. To do this they needed many laborers, some of whom came from the Nuba Mountains.

But such developments were counteracted by another element of British policy, which was to keep the Nuba apart from the Arab populations to avoid the processes of Arabization and Islamization. The British saw that the labor migration created a "detribalized" Nuba. The migrants settled elsewhere in the country, took up Arab and Islamic customs, and showed various signs of cultural change, something the British wanted to 
avoid. Several policies were established to this end. The Closed District Ordinance was introduced in 1922 in order to control the movement of people. The British started to create economic opportunities in Nuba home areas, particularly through the introduction in the early 1920s of the cultivation of cotton as a cash crop. British views on socio-cultural integration between the Nuba and Arabs come out clearly in the field of education. The policies of education show how the administrators experimented with different types of schools and different languages of instruction, as well as with involvement by Christian missionaries, all in order to contain the Nuba as an indigenous group, distinct from the Arabized Muslim population.

British policies also show regional differences. Those areas with an Arab population or a population of Nuba stock that had long been Islamized were treated as "Northern" and offered their education in Arabic, and the Koranic schools (khalwas) were allowed to operate. This applied to the Taqali areas and hence also to the Liri region. The central Nuba areas were treated differently. Here the Government experimented with Christian mission education and also with secular education in kuttāb schools.

The period of Sudanese independence, starting in 1956, represents a continuation of earlier developments towards greater commercialization of the economy, a fact which manifests itself at various levels. Local farmers and pastoralists, to an increasing degree, become involved in the market sector through buying consumer goods and selling crops and animals. In the contemporary Sudan the very survival of rural communities is dependent on this market link. Cash crops are being cultivated at an increasing rate. One expression of the growing importance of the commercial link is that the traditional subsistence crop, sorghum, has become the major cash crop in many areas.

In the southern Nuba Mountains, sorghum is today more important as a cash crop than the "traditional" peanuts and cotton. Alongside the involvement with cash-crops, there is also an involvement in wage labor, either locally or through migration. In southern Kordofan the establishment of mechanized schemes has created new opportunities for wage labor close to where people live and has become an alternative to longdistance migration to the Nile Valley. The earnings from wage labor are today not only an additional source of income for families but a crucial input factor in local cultivation, as wage incomes are spent locally on mobilizing laborers to expand their own cultivation.

A second expression of the increasing rate of commercialization is seen in the expanding trade sector. Indigenous trade in the Sudan has 
traditionally been dominated by the jallāba traders from the Nile Valley. Their command of capital, organizational skills, and links to the political sphere placed them at a great advantage in solving problems inherent to trade. In recent decades, however, new and more profitable options have opened up for these traders. Investments in mechanized farming schemes, as those in Liri, are a case in point. Involvement in exportimport trade and investments in urban housing are other examples of strategies that have made the jallāba leave their involvement in the consumer trade (Manger, 1984).

This has opened up a new field of investment for those people who have been successful in their own traditional adaptation. Income from a good cash crop or from wages helps create small surpluses. The most common way to invest such small surpluses is in petty trading, and many people are doing just that. Continued success can be converted into increased trade in consumer goods and the operation of a permanent shop.

The general picture, then, is no longer a simple dichotomy of subsistence oriented farmers and pastoralists versus the jallāba commercial groups, who are the main agents of commercialization. It is rather a complex setting in which most groups have become deeply involved in the commercial process and are looking for investment opportunities to further improve their position.

\section{Differentiated Change}

The changes sketched out above are not uniform, nor do they affect all Lafofa in the same way. For instance, while doing fieldwork I could clearly see how young men involved in labor migration and local trade were much more inclined to present Islamic identities and to argue for the necessity of adopting Arab customs than were the old-timers. Likewise, among the women, the wives of these migrants showed similar characteristics when compared to their older sisters. Such observations may not be surprising when related to the various economic strategies of the different groups, particularly regarding their involvement in the modern sector as outlined above.

Looking at what type of symbols people make use of to signal their new identities is also enlightening. For instance, today any Lafofa would agree that marrying in a "modern" way and performing circumcision are basic elements of any person's identity; and all Lafofa comply with them, no matter how Arabized or Islamized they are. It is interesting, however, to note that these changes started as individual strategies. People who had contact with the government in the 1920s would start putting on clothes and gradually adopting such practices as circumcision. 
This was partly a strategy, common in central Sudan, to gain prestige through adopting the ways of the dominant groups in the society. Similarly Arab-Islamic marriage customs started to be introduced only in the 1940s. That they became universally valid and accepted customs is to my mind related to the need of a group like the Lafofa, living among Islamic and Arabic-speaking groups, to signal the fact that they were fully human. An undeniable premise for slave hunting, in the period in which the Nuba were a target for slaving expeditions, was the local categorization of the enslavable non-Arab, non-Muslim population as not truly human ( $m \bar{a}$ ins $\bar{a} n \bar{\imath})$, an attitude perhaps reinforced by the fact that in Islamic jurisprudence slaves, when considered as property, were legally classified together with livestock (cf. Encyclopaedia of Islam [1960] 1986 1:26b-27a; Spaulding 1982, 12 and n. 51). With increasing contact, which for the Lafofa started in the late 1920s, it was necessary to deal with this fact. As the customs they adopted were basic to notions of human decency among their neighbors, they became useful markers to express full humanity. In the context, they were general requirements, not a matter of individual belief or choice. Similarly, the differing development of the celebrated Nuba wrestling among boys and girls further illustrates my point. Whereas wrestling has continued among men, celebrating strength and manhood, the female wrestling that took place at harvest times has totally disappeared. Such an activity would definitely collide with an Arab and Islamic view of what a woman should be. Female wrestling thus came to be perceived as similar to nakedness and to the traditional female transition ceremonies, and thus its discontinuation was not viewed as a matter of individual choice but as a matter of fundamental human decency.

This gradual embracing of new elements that would be included in the local Lafofa identity also provided new definitions of what it meant to be a Muslim. For the Lafofa who today want to appear as "pious" Muslims, the act of putting on clothes, or circumcising a child, are not things useful for setting oneself apart from one's fellow Lafofa. New signs have to be utilized. In an earlier paper I have shown how giving up beer drinking among Lafofa migrants can be interpreted in this perspective, demonstrating how one traditional symbol of Lafofa culture has taken on new meaning and has, from being a basic integrative element in ritual and social life, become a part of a stigmatized identity, which leads to its disappearance as people try to deal with that stigma. Similarly, the contemporary pressure to domesticate women can be seen in the same perspective. The traditionally independent role of women has become a sign of following the old Lafofa way of life, and one way to avoid 
accusations of doing this is to present a domestic situation with women in the house, making food and appearing to be under male control.

For a long time, then, the Lafofa have been involved in an interactional game in which they have used signs and symbols to show an Arab and Muslim environment that they are true human beings, that they are persons deserving respect, not slaves and pagans, words almost coterminous in this context. In the Sudan they share this inferior social status in the wider stratificational system with groups like the Ingessana, all of them being known in the Sudan as the zurq (the blue-blacks), which is a derogatory term. Comparing the Nuba with the Arab populations, the distribution of power is clearly in favor of the Arab groups, and against the non-Arabs and non-Muslims. This is related to the long history of Arabization and Islamization in the Sudan, through which local groups have adopted new cultural traits. Many societies went through this process centuries ago, but for the Nuba Mountains it is a contemporary process and a presentation of behavior that can be accepted within the Arab and Islamic code is necessary. The powerdistribution pattern is also evident in the socio-economic field, where the Nuba are mostly at the bottom, serving as cheap labor in urban industries, taking employment as domestic servants, or working as casual labor.

\section{The Islamic Factor}

But are we then left with an analysis showing that the important dynamic forces are only economic and political? I believe not. The Nuba Mountains have certainly seen Islamic missionary activity, operating within the context of the structure of an Islamic Sufi brotherhood, a tariqqa, and these activities have had far reaching repercussions.

The period after the fall of the Mahdi was one of religious unrest in the Sudan, an unrest that also led to incidents in the Nuba Mountains. The problem as viewed by the British was Sufism. The British administration developed a policy of support and encouragement of orthodox Islam, creating a Board of Ulema in 1901, building mosques, appointing judges ( $q \bar{a} d \bar{l} \bar{s})$ to judge according to $\operatorname{shari}^{c} a$ law, and the like (Warburg 1971, 100).

The Sufi brotherhoods, on the other hand, were restricted and regarded as a dangerous form of fanaticism that could create political problems. It is a fact that in the early years of the new century hardly a year passed without some religious uprising or some fuqara being arrested and deported. Death penalties were not uncommon after such uprisings. The uprisings usually started when a local faki declared him- 
self a new mahdi or the $n a b \bar{l}^{c} \bar{I} s \bar{a}$ (the prophet Jesus), secured some supporters, and attacked a British station. The first important uprising took place in 1908, when ${ }^{\mathrm{c}}$ Abd al-Qādir Muhammad Imām Wad Ḥabūba and his followers attacked and killed some British administrators in the Masalamiya district of the Blue Nile Province (ibid., 101).

The uprisings that took place in the Nuba Mountains are of a later date. In 1912 there was an uprising in the Eastern jebels, started by a Tunisian faki. He proclaimed himself mahdi near Jebel Gadir but was shot dead with seven of his followers by the British. This "sharifi uprising," as it is called, was the first of several incidents. For example in 1915 a Fallāta faki, Ahmad ${ }^{c}$ Umar, proclaimed himself nabi ${ }^{c} \bar{I} s \bar{a}$ and retreated to Jebel Gadir, the mountain where the Sudanese Mahdi also had started his activity (ibid., 104).

The British fear of Sufism was well grounded. The Islamic brotherhoods did indeed turn out to be supra-tribal mass organizations, and the roles played by the Anșār of the Mahdist-based Umma Party and the Khatmiya of the Unionist Party in the politics of independent Sudan should suffice as examples. The thin layer of British-made Sudanese clerics could not stop the spread of the Sufi sects, nor attenuate their political importance.

But it is also important to our discussion to note the effects of such brotherhood organizations on the local level. In the south of the Nuba Mountains, the Mukāshifìya branch of the Qādirīya order with its center in the Gezira has been the dominant sect. The history of this tariqa in the southern Nuba Mountains goes back to the beginning of the present century and is related to the coming in 1906 of a faki to work as a missionary. This was Sheikh Burnāwī, a West African, who had been initiated by the leader of the tariqaa, the mukāshif. He traveled around for many years, teaching the locals, as well as taking wives from among them. Eventually he settled down in Liri and built his masid (center, mosque complex) there. After his death his son, Sheikh ${ }^{\mathrm{c}}$ Abd al-Bāqī, took over as religious leader in Liri and still occupied this position when I was doing research there.

Around these leaders a group of followers developed, the dervishes (faqīr, pl. fuqara, also the plural of fakì). These local converts became propagators of the new religion among their own people. The faki performs the Islamic rituals at important events, like name-giving, circumcision, marriage, and funerals. He likewise operates as a healer to the extent that he has been given power (baraka) to do so.

The Qādirīya in Liri is a ritual and organizational unit with the great sheikh at the pivotal point and with lesser sheikhs as his representatives. 
This network of dervishes is very important for teaching illiterate people about Islam. The teaching of Muhammad and the content of the Koran are conveyed through direct contact between a sheikh and his followers. The teaching in such encounters contains various elements of direct relevance for the daily life of the Lafofa. A central theme is what is lawful (halāl) and what is forbidden (harām) in Islam. These teachings can subsequently be used to understand the reality with which the Nuba are confronted. People are told that beer-making and beer-drinking is harām and not tolerated. They are told that women should be protected and not allowed to go shopping or sell produce and that young daughters should be married before their virginity is endangered. In this manner the Lafofa gain knowledge about Islamic standards and can use this knowledge to evaluate themselves and others in relationship to the central problem of being a Muslim or not being one. Thus to a Lafofa being a Muslim also means going to the places where Islamic teaching goes on, be it at a nōba dance, a karāma, a wedding in the village, or the masìd.

But the Islam taught by Sufi groups, and the groups themselves, came under attack by the new fundamentalist regime that took over in Khartoum in 1989. One of the basic issues for this movement has been the struggle for an Islamic constitution in the Sudan, perhaps for reasons suggested by John Voll (1983:131): "As more Sudanese receive a modern style education, simple institution maintenance is not a sufficient expression of their Islamic identity. As a result it is possible to see a growing specifically Islamic content in the programs and platforms of the groups in the Sudan. As this takes place, these statements take on a more explicitly fundamentalist tone." This can be seen generally in the Sudan, as for example in our analysis of the southern Nuba, but also specifically in the changing role of ideology in the north-south conflict. Whereas earlier periods of civil war have been presented, also by the participants themselves, as struggles over economic underdevelopment and of regional power sharing in central politics, the war that started in 1983 has been debated within a different rhetorical universe. The Islamists in the north have indeed used terms such as Dār al-Isläm and Dâr al-Harb, as well as the classification of people as fit to be slaves (an implication of the word ${ }^{c} a b i d$ ), thus bringing the issue of race into the public sphere of Sudanese politics. This is counterbalanced, of course, by John Garang's more secular rhetoric. The maintenance of a penal code based on $\operatorname{shari~}^{c} a$ and the declaration of jihad against the rebels in the south and in the Nuba Mountains both reflect Islamist pressure.

We have already quoted the beginning of the jihad fatwa, here we can conclude by quoting the remainder, to illustrate further what this policy 
does to the "climate" within which the Nuba find themselves. After stigmatizing the non-Muslim rebels in the South as kaffirs and the Muslims fighting with them as apostates, and after further remarking that Islam, as is clear from the Koran, authorizes fighting against and killing their like in a jihad, the document provides additional evidence for this from the Koran, the sunna of the Prophet, and the example of the first caliph Abu Bakr:

2. Another Quranic evidence which supports the stated position, is what Allah has said: "They will continue to fight you (i.e., the enemies of Islam), until you abandon your religion if they could get you to do so, and whoever abandons his religion from amongst you, may them (sic) and their deeds become defunct and a waste here in this life and in the hereafter; surely, they will be condemned permanently to the fire of Hell." 2

3. The justification for killing the rebels, is further supported by what Allah has said in the Quran: "Oh, the prophet of Allah, wage jihad against the kaffirs and the hypocrites, and be tough and heavy-handed with them, as they will [be] destined to Jahannam, and to a fate of misery."

4. The justification for fighting and killing the rebels, is further justified and supported by what the Messenger of Allah, peace be upon him, had (sic) said: "Whoever attempts to divide you, the unity of your purpose, and/or the unity of your Muslim groups or peoples, kill him." A statement reported by a Hadith Chronologist called "Muslim."3

5. Our greatest example in fighting against apostates, is the first Khalifah Abu Bakre El-Siddig, may the blessing of Allah be upon him, who fought against some of the Arabs who deserted Islam. In his most famous statement, he said: "In the name of Allah (swearingly), I will fight those who may differentiate between salat (prayers) and zakat (payment of taxes)"; i.e., those who may fulfill one act of worship and lapse on the other. He also said: "In the name of Allah (swearingly), if the apostates and deserters of religious duties will refuse to pay up a "camel" in tax which they used to pay during the time of the messenger of Allah, peace [be] upon him, I will fight them until they continue to pay these dues." In our Islamic history and heritage, there was also the war which was waged by the Khalifah (successor) Ali Bin Abi Talib, in the battle of "Saffaine."

6. As for those Muslims who cooperate with the rebels, and try to question or doubt the Islamic justifiability of jihad, [they] are hereby classified as "hypo-

\footnotetext{
${ }^{2}$ Cf. n. 1.

${ }^{3}$ The identification of the compiler of one of the two most authoritative collections, for Sunnis, of prophetic sayings and deeds simply as "a Hadith Chronologist called 'Muslim"' may perhaps reflect that the translator had a limited Muslim education or a non-Muslim background.
} 
crites," who are no longer Muslims, and also "apostates" from the religion of Islam; and that (sic) they will be condemned permanently to the fire of Hell.

The Quranic verses which support these claims and our position in general, include the following: "The hypocrites will be condemned to the lowest and worst parts of hell fire"; and what Allah has also said: "Forewarn all the hypocrites that very painful experiences will be inflicted upon them, those who take the kaffirs for guidance, and leadership other than those who believe in Allah, hoping to have through them dignity and wealth; surely, all the dignity and wealth belong to Allah."

\section{Conclusion}

To summarize our empirical argument, the historical changes we have described for the Lafofa and the southern Nuba groups have led to changes in important encounters in which basic socio-cultural relationships and their content are expressed. Changes in such encounters also imply changes in the messages that are communicated and thus form a basis for the development of new notions about the world. On a general level the changes are from an orally based local tradition towards a scripture-based one, in which the class of interpreters of the scripture become major agents of change. Changes in economic life have also added to this process of change, and the movement of people from their mountain villages down to the market places along the mountains has contributed to the disintegration of the mountain cultivation system around which basic rituals were organized.

However, as I said earlier, people do not take over Islam as one unified system and in one process of conversion. Rather, people take up individual customs and practices that become symbols of such conversions. Looking back at the Lafofa adherence to Islam we see that those things that changed first were their notions of physical and sexual shame and their transition ceremonies. From this it appears that basic changes are related to the notion of personhood. We have already indicated that such a process of Islamization has long been important to the Nuba and that it is one basic premise for dealing with the stigma on their identity, a stigma that is related to their earlier status as a group providing slaves. Such changes in the area of identity and personhood also imply basic changes in social relations among the Lafofa.

It is in this perspective that Lafofa Islamization should be interpreted. Many of the changes are not directly tied to Islam as such, but they are made Islamic through the local discourse in the southern Nuba Mountains. As the Lafofa interprete their own position in the wider world, they absorb new elements that provide a basis for a new Lafofa identity which allows for participation in that world. The Lafofa interact and live out 
what we may call the Lafofa culture. But this "culture" will mean different things to different participants, given the differences in their relations to the external world. Migrants do things differently from older men, there are differences between younger and older women, between people holding traditional positions, like the traditional ritual experts, and new converts to Islam.

A general argument in all this is that rather than looking at Islam as an integrated body of beliefs we need to regard Islam in circumstances such as those prevailing in the Nuba Mountains as a collection of practices that people can chose to embrace or not. This is not to say that there is no religious commitment among the Lafofa who call themselves Muslims, but rather that other factors outside the religious field provide constraints on the conversion process itself. This was dramatized in the early 1980s with the introduction in the Sudan of "the September Laws," through which $\operatorname{shari}^{c} a$ became the dominant legal system in the country. I witnessed many times Lafofa and others being brought before the local court to be punished for having drunk beer, or for not adhering to public standards of decency. The acts people received punishment for were not understood by them as being essential to being a Muslim, and the opposition between a locally understood Islam and that based on $\operatorname{sharī}^{c} a$ principles was underlined in such court cases. In the 1990s similar things also went on, but a new dimension was also added to the situation. This was the escalation of the war in Southern Sudan and its spread into the Nuba Mountains. This produced a situation in which the north has declared jihad against the Nuba areas, which of course is a tactical move in a war situation, but which also can be interpreted as an extension into the political field of notions that were already there in the social field.

An interesting observation is that important discourses within Islam are not necessarily about the cosmological dimensions of things. Rather, they revolve around issues of religious practices; they are about issues of morality, and identities. To hold one identity implies not holding another, and how people "choose" such identities can be studied and their arguments about what is proper or not can be listened to. But such "religious" identities go together with other identities that make up a total inventory of identities in a specific place. How such bundles of identities go together will vary, but they are in one way or another couched in Islamic idioms, or are couched in discourses that resonate with the Islamic one. Islam in this sense does not reflect society, it makes sense of it.

Thus we should seek to avoid the old problem of how to classify combinations of so-called Muslim beliefs, customs and identities, and nonMuslim ones. Or rather, the discussion in this paper shows it is a ques- 
tion wrongly put. The issue is not one of classification, but of grasping the content of the discourse itself. Such discourses confer meaning to individual life wherever it is positioned, and help create "identity-space" in which a person can live a life that everywhere, also in Muslim communities, is characterized by change and flux. And, as this paper shows, the content of the discourse can not be decided a priori, but rather must be discovered through ethnographically based research.

\section{REFERENCES}

Asad, Talal. 1986. The Idea of an Anthropology of Islam. Washington, D.C.: Center for Contemporary Arab Studies, Georgetown University.

Barth, Fredrik. 1989. "The Analysis of Culture in Complex Societies." Ethnos 54:120-42

Geertz, Clifford. 1968. Islam Observed: Religious Development in Morocco and Indonesia. Chicago: University of Chicago Press.

Gellner, Ernest. 1981. Muslim Society. Cambridge: Cambridge University Press.

Launay, Robert. 1992. Beyond the Stream: Islam and Society in a West African Town. Berkley: University of California Press.

Lewis, I. M., ed. 1966. Islam in Tropical Africa. London, published for the International African Institute by Oxford U. P.

Manger, Leif Ole., ed.. 1984. Trade and Traders in the Sudan. Bergen: Bergen Studies in Social Anthropology, no. 34.

1992a. "From Slave to Citizen: Processes of Cultural Change among the Lafofa Nuba of Central Sudan." In The Ecology of Choice and Symbol: Festschrift for Fredrik Barth, eds. Reidar Grønhaug, Gunnar Haaland, and Georg Henriksen. Bergen: Alma Mater.

_ 1992b. "On the Study of Islam in Local Contexts." Forum for Development Studies 1.

- 1994. From the Mountains to the Plains: The Integration of the Lafofa Nuba into Sudanese Society. Uppsala: Nordiska Afrikainstitutet.

. 1999. "On Becoming Muslim: The Construction of Identities among the Lafofa of the Sudan." In Leif Manger, ed. Muslim Diversity: Local Islam in Global Contexts. London: Curzon.

O'Fahey, R. S. 1993. "Islamic Hegemonies in the Sudan: Sufism, Mahdism, and Islamism." In Muslim Identity and Social Change in Sub-Saharan Africa, ed. Louis Brenner. London: Hurst.

Spaulding, Jay. 1982. "Slavery, Land Tenure, and Social Class in the Northern Turkish Sudan." International Journal of African Historical Studies 15:1-20.

Voll, John O. 1983. "The Evolution of Islamic Fundamentalism in TwentiethCentury Sudan." In Islam, Nationalism, and Radicalism in Egypt and the Su- 
dan, eds. Gabriel R. Warberg and Uri M. Kupferschmidt. New York: Praeger.

Warberg, Gabriel R. 1971. The Sudan under Wingate: Administration in the Anglo-Egyptian Sudan. London: Frank Cass. 